\title{
Comparison of some epigean and troglobiotic animals regarding their metabolism intensity. Examination of a classical assertion
}

\author{
Tatjana Simčič ${ }^{*}$ and Boris Sket ${ }^{2}$ \\ ${ }^{1}$ Department of Organisms and Ecosystems Research, National Institute of Biology, Večna pot 111, SI-1000 Ljubljana, Slovenia \\ ${ }^{2}$ Biotechnical Faculty, University of Ljubljana, Večna pot 111, SI-1000 Ljubljana, Slovenia
}

\begin{abstract}
This study determines oxygen consumption (R), electron transport system (ETS) activity and R/ETS ratio in two pairs of epigean and hypogean crustacean species or subspecies. To date, metabolic characteristics among the phylogenetic distant epigean and hypogean species (i.e., species of different genera) or the epigean and hypogean populations of the same species have been studied due to little opportunity to compare closely related epigean and hypogean species. To fill this gap, we studied the epigean Niphargus zagrebensis and its troglobiotic relative Niphargus stygius, and the epigean subspecies Asellus aquaticus carniolicus in comparison to the troglobiotic subspecies Asellus aquaticus cavernicolus. We tested the previous findings of different metabolic rates obtained on less-appropriate pairs of species and provide additional information on thermal characteristics of metabolic enzymes in both species or subspecies types. Measurements were done at four temperatures. The values of studied traits, i.e., oxygen consumption, ETS activity, and ratio R/ETS, did not differ significantly between species or subspecies of the same genus from epigean and hypogean habitats, but they responded differently to temperature changes. Higher $Q_{10}$-values for oxygen consumption of $N$. stygius than $N$. zagrebensis in the temperature range $10-20^{\circ} \mathrm{C}$ and higher $E_{a}$ indicated higher thermal sensitivity in the subterranean species. On the other hand, lower $\mathrm{Q}_{10}$ and $\mathrm{E}_{\mathrm{a}}$-values for ETS activity of $N$. stygius than $N$. zagrebensis indicated more thermally stable enzymatic machinery in N. stygius than N. zagrebensis. In Asellus, we observed a similar trend of lower $E_{a}$ for oxygen consumption and higher $E_{a}$ for ETS activity in epigean than the troglomorphic subspecies, but the values did not differ significantly between the two. Our most important conclusion is that the low metabolic rate is not a universal property of troglobiotic animals, and the degree of metabolic adaptation is not necessarily in agreement with the degree of morphological adaptation (troglomorphy).
\end{abstract}

Keywords: food scarcity, temperature, oxygen consumption, ETS activity, amphipod, isopod

Received 1 February 2019; Revised 26 April 2019; Accepted 6 May 2019

Citation: Simčič T. and Sket B., 2019. Comparison of some epigean and troglobiotic animals regarding their metabolism intensity. Examination of a classical assertion. International Journal of Speleology, 48 (2), 133-144. Tampa, FL (USA) ISSN 0392-6672

https://doi.org/10.5038/1827-806X.48.2.2251

\section{INTRODUCTION}

One of the main characteristics of subterranean habitats is food scarcity (Sket, 1996; Hüppop, 2012) which intensifies how animals economize their use of resources. Consequently, one of the most distinctive non-morphological characteristics of subterranean animals was claimed to be a low metabolic rate. A number of studies compared standard metabolic rates (SMRs) in subterranean aquatic species and their epigean relatives. In crustaceans, the SMR in normoxia in epigean species was measured to be 1.6 to 4.5 times higher than in their hypogean relatives (Hervant et al., 1998).
Unfortunately, most comparative studies have been done on less-appropriate pairs of species, usually a hypogean Niphargus sp. and an epigean Gammarus sp., members of Niphargidae and Gammaridae, respectively. Another study compared the hypogean Stenasellus sp. and the epigean Asellus aquaticus, again members of different families, Stenasellidae and Asellidae. While the results are convincing, a small doubt exists, presenting the possibility of phylogenetic and historical reasons for physiological differences. A need to confirm and test this possibility has always been present, particularly since Culver \& Poulson (1971) stated that in Gammarus minus Say, oxygen consumption of a slightly troglomorphic population 
from a well-aerated cave stream was not significantly different from that of epigean (spring) population. Additionally, responses to periodical hypoxia were little different in populations of $G$. minus from cave and surface habitats (Hervant et al., 1999b). Moreover, fasting experiment on the subterranean (Astyanax fasciatus mexicanus) and epigean (Astyanax fasciatus fasciatus) populations of the tropical fish showed that, despite a hypometabolism in cave fishes, they did not recover from the "food deprivation" stress in contrast to epigean ones after the refeeding period (Salin et al., 2010). Accordingly, the metabolic rate is most likely an adaptation to particular environmental conditions (e.g., food availability) rather than simply to the epigean/hypogean realm. Some additional comparisons are needed to clarify this question.

In ectotherm organisms, temperature is one of the most important environmental parameters influencing all biological process rates (Hochachka \& Somero, 2002). Oxygen consumption as an estimator of metabolic activity, and the activities of respiratory enzymes are strongly affected by temperature and, therefore, frequently studied in terms of responses to temperature changes in different groups of organisms (e.g., Muskó et al., 1995; Simčič \& Brancelj, 1997, 2000, 2001, 2004; Simčič, 2005; Simčič et al., 2014; Žagar et al., 2015). However, studies on the thermal physiology of subterranean invertebrates are scarce (Issartel et al., 2005, 2007; MermillodBlondin et al., 2013; Di Lorenzo \& Galassi, 2017). In stable thermal environments, such as subterranean habitats, temperatures may vary a few degrees or even less throughout the year. It is therefore expected that natural selection would favour stenothermal organisms which maximize their performance along a very narrow temperature range compared to epigean animals. However, Issartel et al. (2005), who measured oxygen consumption as a physiological trait at different temperatures, reported that the hypogean Niphargus virei possessed all characteristics of stenothermal organisms, whereas epigean Gammarus fossarum Koch and hypogean Niphargus rhenorodanensis Schellenberg were characterised as eurythermal organisms. They suggested that further studies on "metabolic key" enzymes after exposure to different temperatures could provide additional information on thermal differences between the eurythermal and stenothermal species. Ectotherms can respond to chronic temperature changes by qualitative and/or quantitative adjustments in enzyme activity (Lannig et al., 2003; Simčič \& Brancelj, 2004; Simčič et al., 2014). For example, the temperature-dependence of respiratory electron transport system (ETS) activity reflects changes in the concentration of ETS units resulting from acclimation to changed temperature (Bamstedt, 1980) and characteristics of the enzymatic complexes involved (Packard, 1971). ETS activity is a biochemical measure of potential metabolic activity which can be used for actual oxygen consumption in order to meet current energy demands. Previous studies have shown that the ratio between actual (i.e., oxygen consumption; R) and potential metabolic activities (R/ETS) is an important index of the organisms' metabolism. For example, in organisms with low ratios, the enzyme capacity for elevated metabolism is maintained and, thus, it is available for increased metabolic activity when needed (Muskó et al., 1995; Fanslow et al., 2001; Simčič et al., 2005; Simčič et al., 2017).

Slovenia is an ideal place for such a study as it abounds with troglobiotic fauna. Some species are present in both epigean and troglobiotic subspecies, while other genera are represented by related troglobiotic and epigean species. These include crustacean genera Niphargus (Amphipoda, Niphargidae) and Asellus (Isopoda, Asellidae).

Although all Niphargus spp. seem to be without eyes and feebly pigmented (Fišer, 2012), Niphargus is not an exclusively subterranean genus. Other than hundreds of ecologically diverse subterranean species (Fišer, 2012), more than ten epigean or eutroglophile species exist; more than five of these inhabit Slovenia (Sket, 1958, 1981). For our study, we selected the troglobiotic $N$. stygius (Schioedte) and the epigean (eutroglophile) N. zagrebensis S. Karaman. They are morphologically similar since $N$. stygius is not strongly troglomorphic while $N$. zagrebensis is a member of an epigean species group exhibiting the same degree of a fictitious troglomorphy (compare Sket, 2008). Asellus aquaticus (Linne) is generally a pan-European species (Birštejn, 1951; Sket, 1965, 1994), split into a series of subspecies and/or a closely related species (Sket, 1958; Verovnik et al., 2005, 2009) that are inpart ecologically different, as some are troglobiotic (Racovitza, 1925; Prevorčnik et al., 2002, 2004). Its most troglomorphic subspecies (probably species) is present in Slovenia.

This study aims to compare metabolic activities of closely related epigean and hypogean species or subspecies (within the same genera) and to investigate their sensitivity to temperature change in order to test the previous findings obtained on phylogenetic distant pairs of species and provide additional information on thermal characteristics of the metabolic enzymes in both types of species or subspecies. To this end, oxygen consumption, ETS activity, and R/ETS ratio were determined in two species of genus Niphargus (the epigean species Niphargus zagrebensis and the troglobiotic Niphargus stygius), and two subspecies of genus Asellus (the epigean subspecies Asellus aquaticus carniolicus sket and the troglomorphic subspecies Asellus aquaticus cavernicolus Racovitza) at four experimental temperatures.

\section{MATERIALS AND METHODS}

\section{Experimental animals}

Niphargus stygius (Schioedte 1847) is the type species of the genus. Animals are 10-20 mm long, eyeless, and depigmented. It is strongly troglobiotic, inhabiting systems of fissures in karstified rock and, secondarily, puddles and trickles of seeping water in caves or karst springs primarily in western Slovenia. It is accompanied by other strongly troglobiotic animals. The sample in our study (with mean body mass $\pm \mathrm{SE}=62.2 \pm 5.1 \mathrm{mg}$ wet mass, $\mathrm{n}=10$ ) was taken from 
the cave Unška koliševka at Planina, NE of Postojna in Slovenia. The habitat was a small puddle of percolated water in an artificially modified (for military purposes) cave system.

Niphargus zagrebensis S.Karaman 1950 (syn. N. valachicus $z$., N.elegans $z$.) was first found near Zagreb (NE Croatia) but is also present in SE Slovenia. It occurs in epigean waters where Gammarus spp. are absent and also occurs, albeit rarely, in caves (Delić et al., 2017). In Krakovski gozd at Kostanjevica, SE Slovenia, from where our sample (with $32.5 \pm 3.4 \mathrm{mg}$ wet mass, $\mathrm{n}=10$ ) originates, $N$. zagrebensis inhabits stagnant or slowly flowing water in puddles and ditches with loamy bottoms and rich deposits of fallen leaves. The water is acidic. Access to caves or interstitial water is here mainly absent. $N$. zagrebensis is accompanied by the characteristic synusia, which also accompany other epigean niphargi in eastern Europe and the Near East: Asellus aquaticus, Synurella cf. ambulans, Viviparus sp., Tropidiscus sp., Pisidium spp. Ephemeroptera larvae. While $N$. zagrebensis is eyeless (a characteristic of the genus) and only feebly pigmented, all other animals in this environment are represented by strongly pigmented species.

Isopoda are represented by two subspecies of the highly euryoecious Asellus aquaticus (Linne). Both are in the Ljubljanica drainage (C-SW Slovenia), sympatric, and closely-related phylogenetically (Verovnik et al., 2004), but not syntopic.

Asellus aquaticus carniolicus Sket 1965 is an epigean subspecies. Our sample (with $48.4 \pm 3.1 \mathrm{mg}$ wet mass, $\mathrm{n}=10$ ) is from a large and clear residual pool on the bottom of the intermittent karst lake Cerkniško jezero. The 'lake' is highly productive, rich in fauna (including some fish species), but in summer often without any pools. Temperature is highly fluctuating, as is the oxygen content of the water (Gaberščik, 2002).

Asellus aquaticus cavernicolus Racovitza 1925 is a conspicuously troglomorphic subspecies found in sinking rivers. Our sample (with $29.1 \pm 4.9 \mathrm{mg}$ wet mass, $n=9$ ) was taken in the cave Zelške jame close to Cerkniško jezero. This subspecies is without eyes and dark pigmentation, with very elongated antennae and pereopods (Sket, 1965). The watercourse is influenced by epigean (sink) stream, which is characterised by slight temperature fluctuation and is comparatively rich in food.

The mean yearly temperature (i.e., also the permanent temperature of ground waters) in 20052014 was $9-11^{\circ} \mathrm{C}$ at Postojna and $10-12^{\circ} \mathrm{C}$ at Novo mesto (close to Krakovski gozd). The mean monthly temperatures in January and July varied between -1.7 to $1.4^{\circ} \mathrm{C}$ and 20.5 to $22.8^{\circ} \mathrm{C}$ in Novo mesto, while -2.3 to $4.7^{\circ} \mathrm{C}$ and 18.5 to $22.3^{\circ} \mathrm{C}$ in Postojna (Statistični urad RS, 2018).

\section{Collection and maintenance of animals}

Animals were caught using a hand net three weeks before experiments were conducted. They were stored in plastic bottles and transported to the laboratory, where they were kept in aquaria in perpetual darkness at $10^{\circ} \mathrm{C}\left( \pm 0.5^{\circ} \mathrm{C}\right)$ in thermo-regulated chambers. Aquaria were previously filled with aerated chemically controlled (synthetic) water, i.e., $294 \mathrm{mg} \mathrm{CaCl} \mathrm{Cl}_{2} \times 2 \mathrm{H}_{2} \mathrm{O}$, $123 \mathrm{mg} \mathrm{MgSO}_{4} \times 7 \mathrm{H}_{2} \mathrm{O}, 65 \mathrm{mg} \mathrm{NaHCO}_{3}, 6 \mathrm{mg} \mathrm{KCl}$ were added per $1 \mathrm{~L}$ of bi-distilled water (ISO-standard 6341: 1996). During the period of acclimation to laboratory conditions, Asellus were fed ad libitum with soaked alder leaves, and Niphargus were fed with commercial food (Sera Crabs Natural ${ }^{\mathrm{TM}}$, Germany). Water in the aquaria was changed twice a week.

\section{Methods}

\section{Experimental procedure}

A single experimental animal was transferred to a beaker containing synthetic water and food. The water temperature was then decreased by $1^{\circ} \mathrm{C}$ every $12 \mathrm{~h}$ down to the lowest experimental temperature, i.e., $5^{\circ} \mathrm{C}$. Once the desired temperature was reached, the animals were maintained at this temperature for the next five days for acclimation. On the 4th day of the acclimation period, food was removed from beakers for $24 \mathrm{~h}$ to ensure that the digestive tract would be empty during subsequent oxygen consumption measurements. After oxygen consumption measurements were taken at the first experimental temperature $\left(5^{\circ} \mathrm{C}\right)$, the animals were returned to the beakers, and the same procedure described above was repeated to perform the measurements at 10,15, and $20^{\circ} \mathrm{C}$ (i.e., gradual increasing of temperature followed by 5 -days of acclimation). After oxygen consumption measurements at all four experimental temperatures, water temperature was gradually decreased to $10^{\circ} \mathrm{C}$, where animals were acclimated for five days. Next, prior to the preparation of the homogenate for further analyses, the animals were frozen in liquid nitrogen and stored at $-80^{\circ} \mathrm{C}$.

\section{Oxygen consumption}

Oxygen consumption was estimated by the closed bottle method (Lampert, 1984). The 25-mL groundglass stoppered bottles were filled with synthetic and aerated water from the same, well-mixed, container. The experimental bottles received animals, while two bottles without animals served as controls. All bottles were closed and kept at $5^{\circ} \mathrm{C}, 10^{\circ} \mathrm{C}, 15^{\circ} \mathrm{C}$, or $20^{\circ} \mathrm{C}$. We measured the concentration of dissolved oxygen inside the experimental and control bottles with a sensor and a 4-channel fiber-optic oxygen meter (PreSens OXY-4, Germany) after $0.5 \mathrm{~h}$ to allow animals time to recover from handling stress (start measurement) and $7.5 \mathrm{~h}$ (end measurement). The difference between the concentrations of dissolved oxygen in each experimental bottle at the start and the end of incubation, minus the mean value of control bottles, was taken as the amount of oxygen consumed by animals. Oxygen consumption rate was expressed as $\mathrm{mL} \mathrm{O}_{2}$ per $\mathrm{g}$ wet mass per $\mathrm{h}\left(\mathrm{mL} \mathrm{O}_{2} \mathrm{~g}^{-1} \mathrm{~h}^{-1}\right)$.

\section{ETS activity}

Respiratory electron transport system (ETS) activity was determined as described by Packard (1971) and improved by G.-Tóth (1999). One animal was homogenised in $6 \mathrm{~mL}$ of ice-cold homogenisation buffer $\left(0^{\circ} \mathrm{C}, 0.1 \mathrm{M}\right.$ sodium phosphate buffer $\mathrm{pH}=8.4$, $75 \mu \mathrm{M} \mathrm{MgSO}_{4}, 0.15 \%(\mathrm{w} / \mathrm{v})$ polyvinyl pyrrolidone, 
$0.2 \%(\mathrm{v} / \mathrm{v})$ Triton-X-100) using a glass potter (IKA) and an ultrasonic homogenizer (4710; Cole-Parmer), then centrifuged for $4 \mathrm{~min}$ at $0^{\circ} \mathrm{C}$ at $8500 \mathrm{~g}$ (refrigerated centrifuge Sigma 2K15). Two $0.3 \mathrm{~mL}$ samples from each supernatant were incubated in $1.5 \mathrm{~mL}$ substrate solution $(0.1 \mathrm{M}$ sodium phosphate buffer $\mathrm{pH}=8.4,1.7 \mathrm{mM} \mathrm{NADH}, 0.25 \mathrm{mM} \mathrm{NADPH}, 0.2 \%$ (v/v) Triton-X-100) with $0.5 \mathrm{~mL}$ INT solution $(2.5 \mathrm{mM}$ 2-p-iodo-phenyl 3-p-nitrophenyl 5-phenyl tetrazolium chloride) and incubated for 30 minutes at $5^{\circ} \mathrm{C}, 10^{\circ} \mathrm{C}$, $15^{\circ} \mathrm{C}$, and $20^{\circ} \mathrm{C}$. The reaction was stopped by adding $0.5 \mathrm{~mL}$ of stopping solution (1:1 formalin (conc.): conc. $\mathrm{H}_{3} \mathrm{PO}_{4}$ ). Blanks (substrate and INT solution) were incubated and stopped like in the samples, and then $0.3 \mathrm{~mL}$ of homogenate was added. Formazan production was determined spectrophotometrically from the absorbance of the sample at $490 \mathrm{~nm}$ against the blank (Perkin-Elmer, Lambda 25). ETS activity was measured as the rate of reduction of tetrazolium dye to formazan, converted to equivalent oxygen as described by Kenner and Ahmed (1975), and expressed as $\mathrm{mL} \mathrm{O}_{2}$ per $\mathrm{g}$ wet mass per $\mathrm{h}\left(\mathrm{mL} \mathrm{O}_{2} \mathrm{~g}^{-1} \mathrm{~h}^{-1}\right)$.

\section{Weighing}

After each of the oxygen consumption measurements and at the end of acclimation to $10^{\circ} \mathrm{C}$ before freezing, the animals were placed between two sheets of filter paper and gently pressed together to remove the water from their surface. They were then placed on a preweighed piece of aluminium foil and weighed on an electro-balance (Sartorius BP $210 \mathrm{~S}$ ) with $0.1 \mathrm{mg}$ accuracy.

\section{Calculations and statistics}

Due to the allometric relationship with body size, oxygen consumption and ETS activity data were normalised to a mean wet mass of genera Niphargus and Asellus, separately. The size range of our experimental animals was much too narrow to determine a mass exponent $\mathrm{b}$. Therefore, we used $b=0.66$ for oxygen consumption (Simčič et al., 2012) and 0.65 for ETS activity (Simčič \& Brancelj, 2003) determined for freshwater crustaceans to normalise measured data.

To characterize the sensitivity of oxygen consumption and ETS activity to temperature changes, the temperature coefficient, $\mathrm{Q}_{10}$, was calculated according to the equation (Lampert, 1984):

$$
\mathrm{Q}_{10}=\left(\mathrm{R}_{2} / \mathrm{R}_{1}\right)^{\left(10 /\left(\mathrm{T}_{2}-\mathrm{T}_{1}\right)\right)}
$$

where $R_{1}$ and $R_{2}$ are the measured metabolic rates and $T_{1}$ and $T_{2}$ the corresponding temperatures. $Q_{10^{-}}$ values were calculated for two temperature ranges, i.e., temperature range $5-10^{\circ} \mathrm{C}$, to obtain the response of metabolic activities to the decrease of temperature, and temperature range $10-20^{\circ} \mathrm{C}$ to estimate the sensitivity to temperature increase $\left(10^{\circ} \mathrm{C}\right.$ is an average temperature of the habitats).

The thermodynamic response of oxygen consumption and ETS activity over the whole temperature range was shown in terms of the Arrhenius activation energy $\left(E_{a}\right)$, which describes the accelerating influence of temperature on metabolic rate. This calculation was obtained from the slope of linear regression of $\ln$ of actual or potential metabolic rate against the inverse of absolute temperature (Mermillod-Blondin et al., 2013) according to the equation:

$$
\mathrm{E}_{\mathrm{a}}=-\mathrm{R}_{\mathrm{gc}} \mathrm{S}
$$

where $\mathrm{E}_{\mathrm{a}}$ is expressed in $\mathrm{kJ} \mathrm{mol}^{-1}, \mathrm{R}_{\mathrm{gc}}$ is the gas constant $\left(8.31 \mathrm{~J} \mathrm{~mol}^{-1}\right.$ degree $\left.^{-1}\right)$, and $\mathrm{S}$ is the slope of the Arrhenius plot.

The normal distribution of data was tested with the Shapiro-Wilk test and equality of variances with Levene's test. In the case of inconsistency, data were $\log$ transformed. Prior to pooling the data sets of both sexes in Niphargus zagrebensis, N. stygius and Asellus aquaticus cavernicolus (specimens of $A$. a. carniolicus were all males), we tested for between-sex variation in oxygen consumption, ETS activity, and R/ETS ratio using an ANCOVA with sex as a factor and mass as a covariate, which showed no significant differences between sexes $(p>0.05)$, therefore we pooled both sexes prior to interspecific comparison.

A two-way mixed model (between/within) ANOVA was carried out to test for differences in oxygen consumption rate, ETS activity, and R/ETS ratio between different populations (between-subject factor) and experimental temperatures (within-subject factor). Tukey's HSD post hoc comparison was used to determine which means differed significantly. For finding interspecific differences in $Q_{10}$ within genera in temperature ranges we applied Student t-tests. We compared the slopes of the linear regressions between epigean and hypogean animals within the same genus using ANCOVA to determine whether they had significantly different $E_{a}$. We conducted all statistical analyses with SPSS 20.0 (SPSS Inc. Chicago, Illinois, USA).

\section{RESULTS}

\section{Oxygen consumption}

The oxygen consumption rate ranged between 0.07 and $0.09 \mathrm{~mL} \mathrm{O}_{2} \mathrm{~g}^{-1} \mathrm{~h}^{-1}$ for $N$. zagrebensis and between 0.06 and $0.12 \mathrm{~mL} \mathrm{O}_{2} \mathrm{~g}^{-1} \mathrm{~h}^{-1}$ for $N$. stygius (Fig 1a). Oxygen consumption rate increased significantly with temperature (ANOVA; $F_{3,54}=14.39$; $\mathrm{p}<0.001$ ), and it was similar between both species (ANOVA; $\mathrm{F}_{1,18}=0.09 ; \mathrm{p}>0.05$ ). Interaction temperature $\times$ population was non-significant (ANOVA; $F_{3,54}=3.82$; $\mathrm{p}>0.05$ ). We observed a significant increase in oxygen consumption rate in $N$. stygius at $20^{\circ} \mathrm{C}$.

In Asellus, the oxygen consumption rate increased significantly with temperature (ANOVA; $\mathrm{F}_{3,39}=14.97$; $\mathrm{p}<0.001$ ), from 0.03 to $0.11 \mathrm{~mL} \mathrm{O}_{2} \mathrm{~g}^{-1} \mathrm{~h}^{-1}$ in Asellus aquaticus carniolicus and from $0.02 \mathrm{~mL} \mathrm{O}_{2} \mathrm{~g}^{-1} \mathrm{~h}^{-1}$ to $0.08 \mathrm{~mL} \mathrm{O}_{2} \mathrm{~g}^{-1} \mathrm{~h}^{-1}$ in A. a. cavernicolus (Fig. 1b). Significantly higher oxygen consumption was measured in A. a. carniolicus at $20^{\circ} \mathrm{C}$ in comparison to lower experimental temperatures. The rates of oxygen consumption did not differ between both subspecies (ANOVA; $\left.\mathrm{F}_{1,13}=0.006 ; \mathrm{p}>0.05\right)$. There was a nonsignificant temperature $\times$ population interaction (ANOVA; $\mathrm{F}_{3,39}=2.14 ; \mathrm{p}>0.05$ ).

In the temperature range $5-10^{\circ} \mathrm{C}, \mathrm{Q}_{10}$-values of respiration for $N$. zagrebensis were similar to those 
of $N$. stygius (Student's t-test; p > 0.05), while in the temperature range $10-20^{\circ} \mathrm{C}$ higher $Q_{10}$ values were obtained for $N$. stygius than for $N$. zagrebensis (Student's t-test; $\mathrm{p}<0.05$ ) (Table 1).

$\mathrm{Q}_{10}$-values of respiration for genus Asellus were lower in epigean $A$. a. carniolicus than troglobiotic A. a. cavernicolus in the temperature range $5-10^{\circ} \mathrm{C}$ ( $\mathrm{p}<0.05$ ), but the opposite was observed in the temperature range $10-20^{\circ} \mathrm{C}$, where $\mathrm{Q}_{10}$-values of $A$. $a$. carniolicus were higher than those of $A$. a. cavernicolus $(\mathrm{p}<0.05)$ (Table 1).

The Arrhenius activation energy $\left(E_{a}\right)$ of oxygen consumption was lower for epigean $N$. zagrebensis than for hypogean $N$. stygius (ANCOVA; p < 0.01). In genus Asellus, the same trend of lower $\mathrm{E}_{\mathrm{a}}$ in epigean than troglobiotic subspecies was observed, but the values did not differ significantly between the two subspecies (ANCOVA; $p$ > 0.05) (Table 2).

\section{ETS activity}

ETS activity varied with temperature from $0.29 \mathrm{~mL} \mathrm{O}_{2}$ $\mathrm{g}^{-1} \mathrm{~h}^{-1}$ to $1.68 \mathrm{~mL} \mathrm{O}_{2} \mathrm{~g}^{-1} \mathrm{~h}^{-1}$ in $N$. zagrebensis and from 0.38 to $1.45 \mathrm{~mL} \mathrm{O}_{2} \mathrm{~g}^{-1} \mathrm{~h}^{-1}$ in $N$. stygius (Fig. 2a). ETS activity did not differ significantly between species of Niphargus (ANOVA; $\left.\mathrm{F}_{1,17}=0.21 ; \mathrm{p}>0.05\right)$, but temperature had significant effect on ETS activity (ANOVA; $\mathrm{F}_{3,51}=550.37$; $\mathrm{p}<0.001)$. Interaction temperature $\times$ population was significant (ANOVA; $\mathrm{F}_{3,51}=11.98 ; \mathrm{p}<0.001$ ).

ETS activity was similar in both taxa of Asellus within the same temperatures $\left(\mathrm{F}_{1,13}=0.52 ; \mathrm{p}>0.05\right)$
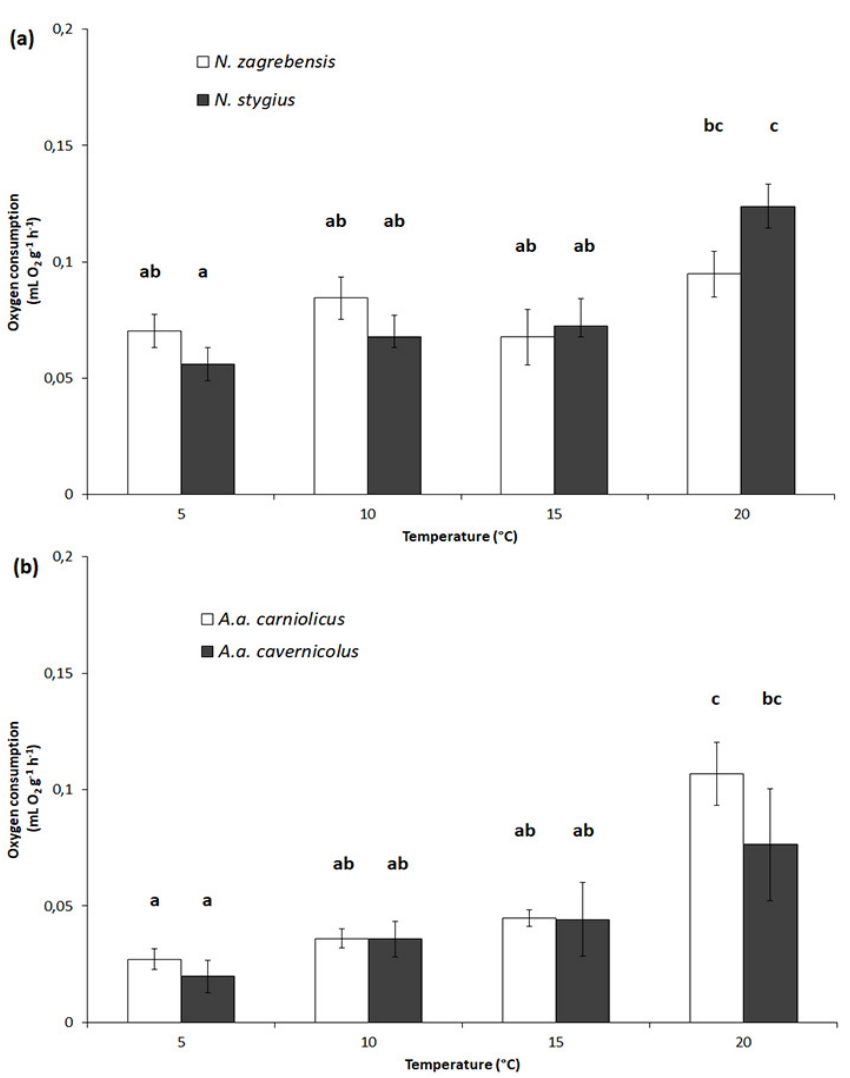

Fig. 1. Oxygen consumption of (a) Niphargus zagrebensis and $N$. stygius and (b) Asellus aquaticus carniolicus and A.a. cavernicolus at four experimental temperatures. Bars labelled with different letters differ significantly $-p<0.05$ (ANOVA, Tukey's HSD test). Error bars represent mean \pm SE ( $n=10$ for Niphargus and $n=5-10$ for Asellus).

Table 1. Temperature coefficient $\mathrm{Q}_{10}$ of oxygen consumption $(\mathrm{R})$ and ETS activity (ETS) calculated for Niphargus zagrebensis, $N$. stygius, Asellus aquaticus carniolicus and A.a. cavernicolus for temperature ranges $5-10^{\circ} \mathrm{C}$ and $10-20^{\circ} \mathrm{C}$. (mean $\pm \mathrm{SE} ; \mathrm{n}=10$ for Niphargus and $\mathrm{n}=5-10$ for Asellus). Significant differences between the populations of the same genus for R or ETS are marked with * $(p<0.05)$

\begin{tabular}{|c|c|c|c|c|c|c|c|c|}
\hline \multirow[t]{2}{*}{ T range $\left({ }^{\circ} \mathrm{C}\right)$} & \multicolumn{2}{|c|}{ N. zagrebensis } & \multicolumn{2}{|c|}{ N. stygius } & \multicolumn{2}{|c|}{ A.a. carniolicus } & \multicolumn{2}{|c|}{ A.a. cavernicolus } \\
\hline & $\mathbf{R}$ & ETS & $\mathbf{R}$ & ETS & $\mathbf{R}$ & ETS & $\mathbf{R}$ & ETS \\
\hline $5-10$ & $\begin{array}{c}2.21 \\
\pm 0.62\end{array}$ & $\begin{array}{l}4.28^{*} \\
\pm 0.65\end{array}$ & $\begin{array}{c}2.50 \\
\pm 0.82\end{array}$ & $\begin{array}{l}2.60^{*} \\
\pm 0.25\end{array}$ & $\begin{array}{l}3.30^{*} \\
\pm 1.52\end{array}$ & $\begin{array}{l}3.18^{*} \\
\pm 0.29\end{array}$ & $\begin{array}{c}14.08^{*} \\
\pm 6.19\end{array}$ & $\begin{array}{l}6.42^{*} \\
\pm 0.98\end{array}$ \\
\hline $10-20$ & $\begin{array}{l}1.19^{*} \\
\pm 0.13\end{array}$ & $\begin{array}{l}3.08^{*} \\
\pm 0.20\end{array}$ & $\begin{array}{l}1.91^{*} \\
\pm 0.17\end{array}$ & $\begin{array}{l}2.41^{*} \\
\pm 0.08\end{array}$ & $\begin{array}{l}5.54^{*} \\
\pm 1.77\end{array}$ & $\begin{array}{c}3.12 \\
\pm 0.10\end{array}$ & $\begin{array}{l}1.79^{*} \\
\pm 0.21\end{array}$ & $\begin{array}{c}2.91 \\
\pm 0.30\end{array}$ \\
\hline
\end{tabular}

Table 2. Arrhenius activation energy $\mathrm{E}_{\mathrm{a}}\left(\mathrm{kJ} \mathrm{mol}^{-1}\right)$ of oxygen consumption (R) and ETS activity (ETS) calculated for Niphargus zagrebensis, N. stygius, Asellus aquaticus carniolicus and A.a. cavernicolus over temperature range $5-20^{\circ} \mathrm{C}$. Significant differences between the populations of the same genus for R or ETS are marked with ${ }^{* *}(p<0.01)$.

\begin{tabular}{|c|c|c|}
\cline { 2 - 3 } \multicolumn{1}{c|}{} & \multicolumn{2}{c|}{$\mathbf{E}_{\mathbf{a}}$} \\
\cline { 2 - 3 } \multicolumn{1}{c|}{} & $\mathbf{R}$ & $\mathbf{E T S}$ \\
\hline Niphargus zagrebensis & $8.1^{* *}$ & $81.7^{* *}$ \\
\hline Niphargus stygius & $35.8^{* *}$ & $61.1^{* *}$ \\
\hline Asellus aquaticus carniolicus & 59.7 & 75.3 \\
\hline Asellus aquaticus cavernicolus & 77.9 & 85.0 \\
\hline
\end{tabular}

and ranged from 0.21 to $1.15 \mathrm{~mL} \mathrm{O}_{2} \mathrm{~g}^{-1} \mathrm{~h}^{-1}$ in epigean A. a. carniolicus and from 1.19 to $1.30 \mathrm{~mL} \mathrm{O}_{2} \mathrm{~g}^{-1} \mathrm{~h}^{-1}$ in troglomorphic A. a. cavernicolus (Fig. 2b). ETS activity increased significantly with temperature (ANOVA; $\left.\mathrm{F}_{3,39}=603.17 ; \mathrm{p}<0.001\right)$. Significant interaction temperature $\times$ population was observed (ANOVA; $\left.\mathrm{F}_{3,39}=6.11 ; \mathrm{p}<0.01\right)$.

$\mathrm{Q}_{10}$-values of ETS activity were higher for $N$. zagrebensis than $N$. stygius in the temperature ranges $5-10^{\circ} \mathrm{C}$ and $10-20^{\circ} \mathrm{C}$ (Student's t-test; $\mathrm{p}<0.05$ ) (Table 1).
Higher $\mathrm{Q}_{10}$-values were obtained for $A$. a. cavernicolus than A. a. carniolicus in the temperature ranges $5-10^{\circ} \mathrm{C}$ (Student's t-test; $\mathrm{p}<0.05$ ), but similar values were observed in the temperature range $10-20^{\circ} \mathrm{C}$ (Student's t-test; $\mathrm{p}>0.05$ ) (Table 1).

$\mathrm{E}_{\mathrm{a}}$ of ETS activity ranged from $61.1 \mathrm{~kJ} \mathrm{~mol}^{-1}$ for $N$. stygius to $85 \mathrm{~kJ} \mathrm{~mol}^{-1}$ for A.a. cavernicolus (Table 2). $N$. zagrebensis had significantly higher $\mathrm{E}_{\mathrm{a}}$ than $N$. stygius (ANCOVA; $\mathrm{p}<0.01$ ), whereas $\mathrm{E}_{\mathrm{a}}$-values of the Asellus subspecies did not differ significantly (ANCOVA; $\mathrm{p}>0.05$ ). 

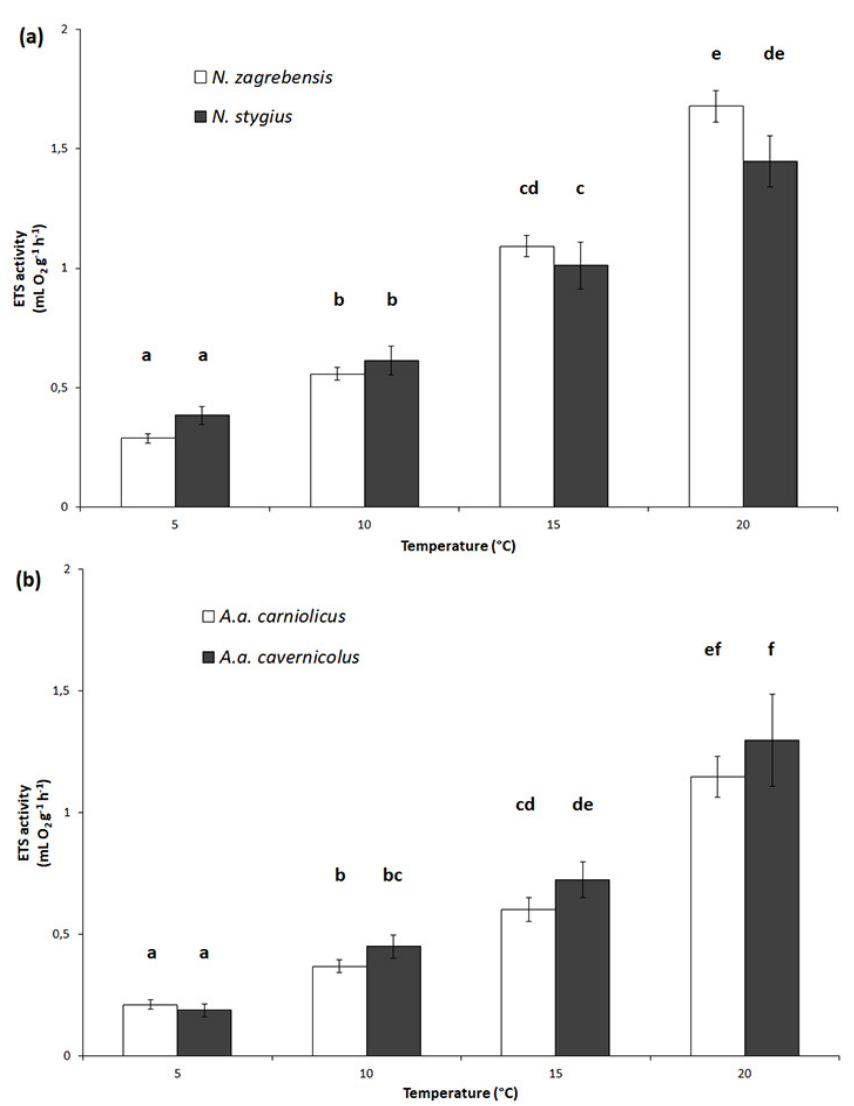

Fig. 2. Electron transport system (ETS) activity of (a) Niphargus zagrebensis and $N$. stygius and (b) Asellus aquaticus carniolicus and A.a. cavernicolus at four experimental temperatures. Bars labelled with different letters differ significantly $-p<0.05$ (ANOVA, Tukey's HSD test). Error bars represent mean \pm SE $(n=9-10$ for Niphargus and $\mathrm{n}=5-10$ for Asellus).

\section{The relationship between oxygen consumption and ETS activity}

The ratio between oxygen consumption and ETS activity (R/ETS), an indicator of exploitation of metabolic potential for actual metabolic activity, ranged from 5.73 to $25.09 \%$ in $N$. zagrebensis and between 8.85 and $16.09 \%$ in $N$. stygius (Fig. 3a). $\mathrm{R} / \mathrm{ETS}$ ratio decreased significantly with temperature (ANOVA; $\mathrm{F}_{3,51}=38.54 ; \mathrm{p}<0.001$ ). Similar values were observed between both species (ANOVA; $\mathrm{F}_{1,17}=0.02$; $\mathrm{p}>0.05)$ and interaction temperature $\times$ population was non-significant (ANOVA; $\mathrm{F}_{1,17}=0.02 ; \mathrm{p}>0.05$ ).

$\mathrm{R} / \mathrm{ETS}$ ratios ranged from 8.11 to 12.76 and 6.91 to 15.92 in A. a. carniolicus and A. a. cavernicolus, respectively (Fig. $3 b$ ). The values did not differ significantly between taxa (ANOVA; $\mathrm{F}_{1,13}=0.03 ; \mathrm{p}>$ 0.05 ) and temperatures (ANOVA; $F_{3,39}=2.50 ; p>0.05$ ). There was a non-significant interaction temperature $x$ population (ANOVA; $\mathrm{F}_{3,39}=01.75 ; \mathrm{p}>0.05$ ).

\section{DISCUSSION}

The values of studied metabolic traits, i.e., oxygen consumption, metabolic potential (measured as ETS activity), and the ratio R/ETS, did not differ significantly between the epigean and troglobiotic taxa of the same genus from epigean and hypogean habitats, but they responded differently to temperature changes.

In the present study, we measured routine metabolic rate. The routine metabolic rate of cave animals may be reduced due to reduced activity (Hervant et al.,
2001). However, our results are in accord with results in previously studied subspecies of Gammarus minus as presented by Culver \& Poulson (1971), who found that cave ecotypes of $G$. minus showed no lower standard or routine metabolic rate than surface ecotypes (Table 3). Oxygen consumption rate of $N$. stygius in the present study is in accord with that found in the previous study of Simčič et al. (2005), where similar values were reported also for a cave population of the eutroglophile Niphargus species, N. krameri Schellenberg. Moreover, we obtained a similar oxygen consumption rate in our study for the epigean $N$. zagrebensis. Additionally, oxygen consumption did not differ between both studied Asellus subspecies: the highly troglomorphic A. $a$. cavernicolus and epigean $A$. a. carniolicus. This finding means that changes of the metabolism intensity are not necessarily in agreement with the degree of morphological adaptation (troglomorphy). In contrast, all previous studies comparing hypogean and epigean species of different and not closely related families showed lower oxygen consumption for hypogean than epigean animals, suggesting that phylogenetic and historical grounds contribute at least partly to the physiological differences between the more distantly related hypogean and epigean species.

Measurements of ETS activity showed similar metabolic potential for species and subspecies within the genera Niphargus and Asellus, respectively. This result agrees with the previous finding of Simčič et
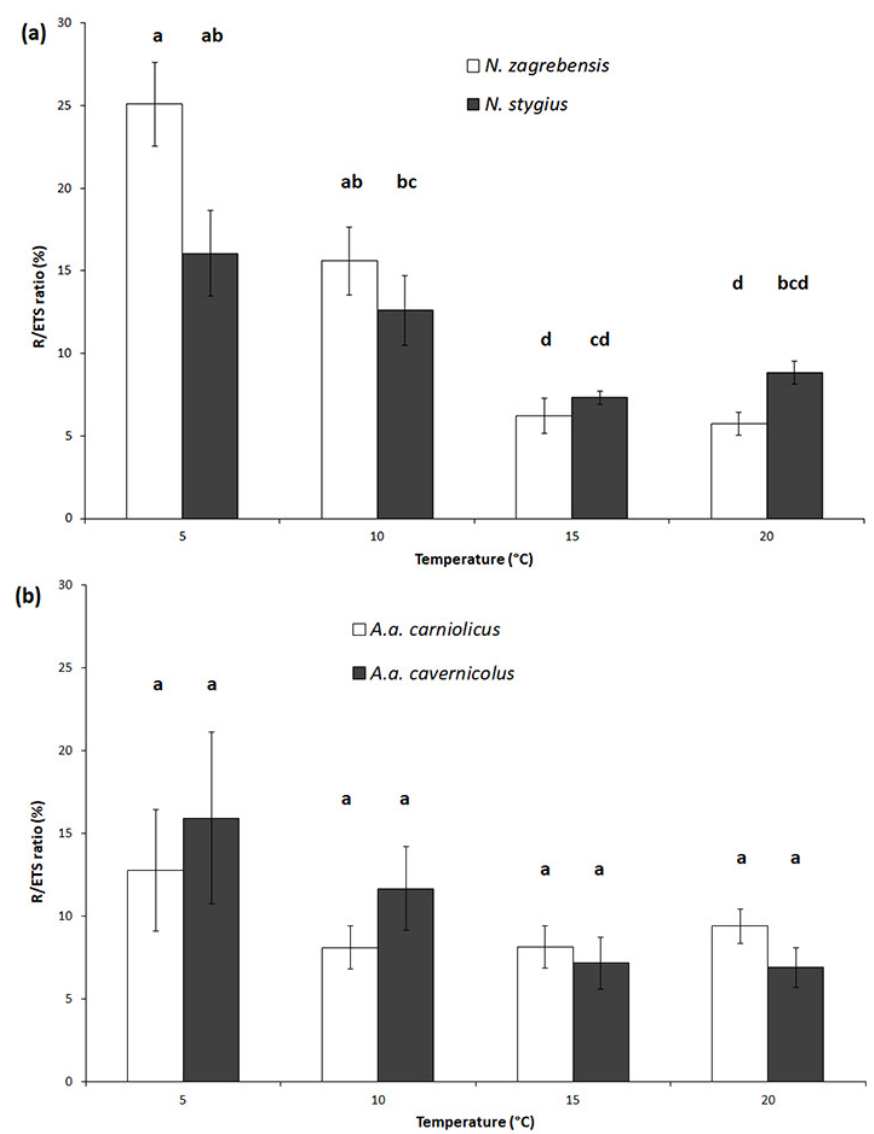

Fig. 3. Exploitation of metabolic potential for actual metabolic activity (R/ETS ratio) for (a) Niphargus zagrebensis and N. stygius and (b) Asellus aquaticus carniolicus and A.a. cavernicolus. Bars labelled with different letters differ significantly $-p<0.05$ (ANOVA, Tukey's HSD test). Error bars represent mean \pm SE ( $n=9-10$ for Niphargus and $\mathrm{n}=5-9$ for Asellus). 
al. (2005) where ETS activity did not differ between Gammarus and Niphargus amphipod species. It was assumed that hypogean animals possess relatively high metabolic potential, which can be exploited for energy production immediately following a pulse in the food supply. When food is available after prolonged starvation, it is ecologically advantageous for organisms to quickly and completely restore energy reserves that were depleted during starvation (Hervant \& Renault, 2002).

Table 3. Oxygen consumption and electron transport system (ETS) activity in epigean (E) and hypogean (H) crustaceans from various studies. Mintermediate ecotype; data for close to $10^{\circ} \mathrm{C}$ have been taken.

\begin{tabular}{|c|c|c|c|c|c|c|}
\hline Taxon & Location & Type & $\begin{array}{l}\text { Oxygen consumption } \\
\qquad\left(\mu \mathrm{L} \mathrm{O} \mathrm{O}_{2} \mathrm{~g}^{-1} \mathrm{~h}^{-1}\right)\end{array}$ & $\begin{array}{l}\text { ETS activity } \\
\left(\mu \mathrm{L} \mathrm{O}_{2} \mathrm{~g}^{-1} \mathbf{h}^{-1}\right)\end{array}$ & $\mathbf{T}\left({ }^{\circ} \mathbf{C}\right)$ & Source \\
\hline Niphargus zagrebensis & Krakovski gozd (Slovenia) & $\mathrm{E}$ & 84 & 557 & 10 & Present study \\
\hline Niphargus stygius & Planinsko polje (Slovenia) & $\mathrm{H}$ & 68 & 613 & 10 & Present study \\
\hline Niphargus stygius & $\begin{array}{l}\text { Velika Pasjica Cave } \\
\text { (Slovenia) }\end{array}$ & $\mathrm{H}$ & 58 & 459 & 10 & $\begin{array}{c}\text { Simčič et al. } \\
(2005)\end{array}$ \\
\hline Niphargus stygius & Špicberg Cave (Slovenia) & $\mathrm{H}$ & 85 & 383 & 10 & $\begin{array}{l}\text { Simčič et al. } \\
(2005)\end{array}$ \\
\hline Niphargus krameri & Dimnice Cave (Slovenia) & $\mathrm{H}$ & 65 & 390 & 10 & $\begin{array}{c}\text { Simčič et al. } \\
(2005)\end{array}$ \\
\hline Niphargus virei & Spring at Gueux (France) & $\mathrm{H}$ & 80 & - & 11 & $\begin{array}{l}\text { Hervant et al. } \\
\text { (1997) }\end{array}$ \\
\hline $\begin{array}{c}\text { Niphargus } \\
\text { rhenorhodanensis }\end{array}$ & $\begin{array}{c}\text { Groundwater in Dombes } \\
\text { Forest (France) }\end{array}$ & $\mathrm{H}$ & 132 & - & 11 & $\begin{array}{l}\text { Hervant et al. } \\
\text { (1997) }\end{array}$ \\
\hline Gammarus fossarum & $\begin{array}{l}\text { River in Pouillyles- } \\
\text { Nonains (France) }\end{array}$ & $\mathrm{E}$ & 195 & - & 11 & $\begin{array}{c}\text { Hervant et al. } \\
(1997)\end{array}$ \\
\hline Gammarus fossarum & $\begin{array}{l}\text { Hudournik Spring } \\
\text { (Slovenia) }\end{array}$ & $\mathrm{E}$ & 178 & 449 & 10 & $\begin{array}{c}\text { Simčič et al. } \\
(2005)\end{array}$ \\
\hline Gammarus fossarum & River Iščica (Slovenia) & $\mathrm{E}$ & 165 & 386 & 10 & $\begin{array}{c}\text { Simčič et al. } \\
(2005)\end{array}$ \\
\hline Gammarus minus I & Benedict Cave (USA) & $\mathrm{H}$ & 430 & - & 13 & $\begin{array}{c}\text { Culver \& Poulson } \\
(1971)\end{array}$ \\
\hline Gammarus minus I & Greenbrier Caverns (USA) & $\mathrm{H}$ & 340 & - & 13 & $\begin{array}{c}\text { Culver \& Poulson } \\
(1971)\end{array}$ \\
\hline Gammarus minus II & Coffman's Cave (USA) & M & 260 & - & 13 & $\begin{array}{c}\text { Culver \& Poulson } \\
(1971)\end{array}$ \\
\hline Gammarus minus III & $\begin{array}{l}\text { Fort Spring } \\
\text { (USA) }\end{array}$ & $\mathrm{E}$ & 210 & - & 13 & $\begin{array}{c}\text { Culver \& Poulson } \\
(1971)\end{array}$ \\
\hline Gammarus minus III & U.S. \#219 spring (USA) & $\mathrm{E}$ & 520 & - & 13 & $\begin{array}{c}\text { Culver \& Poulson } \\
(1971)\end{array}$ \\
\hline $\begin{array}{l}\text { Asellus aquaticus } \\
\text { carniolicus }\end{array}$ & $\begin{array}{l}\text { Cerkniško jezero } \\
\text { (Slovenia) }\end{array}$ & $\mathrm{E}$ & 36 & 368 & 10 & Present study \\
\hline $\begin{array}{l}\text { Asellus aquaticus } \\
\text { cavernicolus }\end{array}$ & Zelške jame (Slovenia) & $\mathrm{H}$ & 36 & 450 & 10 & Present study \\
\hline Asellus aquaticus & Rhône River (France) & $\mathrm{E}$ & 280 & - & 11 & $\begin{array}{l}\text { Hervant et al. } \\
\text { (1997) }\end{array}$ \\
\hline Stenasellus virei & $\begin{array}{c}\text { Groundwater of River } \\
\text { Tarn (France) }\end{array}$ & $\mathrm{H}$ & 92 & - & 11 & $\begin{array}{l}\text { Hervant et al. } \\
\text { (1997) }\end{array}$ \\
\hline
\end{tabular}

The R/ETS ratio is a useful estimate of organisms' metabolic state. In the present study, similar ratios were obtained for epigean and hypogean animals within the same genus. This means that the animals from subterranean and surface habitats exploited a similar percentage of the metabolic potential for actual oxygen consumption. The values of R/ETS for species of Niphargus at $10^{\circ} \mathrm{C}$ are similar to those reported in Simčič et al. (2005) for Niphargus species from different hypogean habitats that were determined at the same temperature. Moreover, the ratios differed significantly between hypogean amphipod populations of $N$. stygius from different caves and $N$. krameri (Simčič et al., 2005). It was suggested that the reason for different ratios probably lies in differences in the quality and/or quantity of food available in their natural habitats (Simčič et al., 2005). Since animals were used in experiments immediately after being collected in caves, the different food supply had a significant effect on the experimental animals' oxygen consumption. Moreover, the feeding experiments showed that ETS activity in $N$. stygius did not change with feeding, although oxygen consumption increased significantly in fed animals (Simčič et al., 2005). These results are in agreement with those of Cammen et al. (1990) and Mezek et al. (2010), who found that oxygen consumption declined over time in starved animals, but ETS activity remained relatively constant. Therefore, feeding hypogean animals affected oxygen consumption and ETS activity differently, where fed $N$. stygius had higher exploitation of metabolic potential than the starved ones (Simčič et al., 2005). However, in the present study, the experimental animals were kept in a laboratory for three weeks and fed ad libitum. Because of this, the direct effect of quality and/or quantity of food in their natural habitats on oxygen consumption was excluded.

Metabolism in ectotherms is highly dependent on environmental temperature, therefore we also tested both types of species and subspecies for their 
responses to temperature change. As expected, oxygen consumption and ETS activity increased with temperature (Hochachka \& Somero, 2002). However, different responses to temperature changes were observed between oxygen consumption rate and ETS activity. ETS activity is a direct enzymatic process that depends upon enzyme concentration (Bamstedt, 1980) and thermal characteristics of the enzymes (Packard, 1971), whereas oxygen consumption is a complex physiological process, also modulated by changes in substrate concentration and structure of lipid membranes (Angilletta, 2009). In general, the $\mathrm{R} / \mathrm{ETS}$ ratios decreased with increasing temperature in all studied taxa. This response of R/ETS ratio to temperature changes is in accord with the results of previous studies in invertebrate (Muskó et al., 1995; Simčič \& Brancelj, 1997; Simčič, 2005) and vertebrate (Žagar et al., 2015; Simčič et al., 2017) species. Significant interaction between temperature and population observed for both studied genera indicates that the response of ETS activity to particular temperature depends on subspecies or species. This topic is discussed in detail below.

In our study, $\mathrm{Q}_{10}$-values for oxygen consumption were similar for both Niphargus species in the temperature range $5-10^{\circ} \mathrm{C}$, but $\mathrm{Q}_{10}$-values for ETS activity were higher for $N$. zagrebensis than $N$. stygius. Moreover, in the temperature range $10-20^{\circ} \mathrm{C}$, lower $\mathrm{Q}_{10}$-value for ETS activity was also obtained in $N$. stygius than $N$. zagrebensis. However, oxygen consumption increased with temperature more in $N$. stygius than $N$. zagrebensis. It is known that adaptive mechanisms increase metabolic efficiency at low temperature and decrease it at high temperature, thus achieving homeostatic control over their enzyme reaction (Packard et al., 1975), but the ability for capacity acclimation is genetically limited (Prosser, 1991). Low $Q_{10}$ is characteristic of animals that possess enzyme systems with extremely broad temperature optima, which prevents their inactivation during environmental temperature changes (Randall et al., 1997). Therefore, lower $Q_{10}$-values for ETS activity in $N$. stygius than $N$. zagrebensis indicated more thermally stable enzymatic machinery in $N$. stygius than $N$. zagrebensis in both temperature ranges (Table 1). Contrary to $\mathrm{Q}_{10}$ for ETS activity, higher $\mathrm{Q}_{10^{-}}$ values for oxygen consumption in $N$. stygius than $N$. zagrebensis in the temperature range $10-20^{\circ} \mathrm{C}$ indicate a stress response to increased temperature, because increased oxygen consumption rate is one of the indicators of stress (Barton \& Schreck, 1987; Simčič \& Brancelj, 2007). Moreover, as evidenced by Simčič \& Brancelj (2007) and Lukančič et al. (2010) for various invertebrate species, a higher R/ ETS ratio at higher temperatures could indicate a stress response. In the present study, we observed a trend of increasing of the R/ETS ratio at the highest temperature for $N$. stygius, but not for $N$. zagrebensis. In the case of genus Asellus, we observed the highest $\mathrm{Q}_{10}$-value for oxygen consumption for the hypogean subspecies in the temperature range $5-10{ }^{\circ} \mathrm{C}$ and the lowest for the same subspecies at temperature range $10-20^{\circ} \mathrm{C}$. Extreme responses to temperature are in agreement with those of Issartel et al. (2005), who reported very low and high $\mathrm{Q}_{10}$-values for hypogean stenothermal Niphargus virei as a result of the negative influence of temperature on biochemical and physiological processes (Table 4). On the other hand, Issartel et al. (2005) found that the hypogean $N$. rhenorhodanensis showed characteristics of eurythermal animals, although it lives in strongly buffered habitats. The differences in physiological pattern, regarding temperature, in hypogean $\mathrm{N}$. virei and $N$. rhenorhodanensis were likely a result of their biogeographical history (Issartel et al., 2005; Foulquier et al., 2008). Therefore, other environmental factors, besides seasonal temperature variation in the habitats, could affect the thermal sensitivity of animals. Additionally, Di Lorenzo \& Galassi (2017) obtained the controversial results for a stygobiotic copepod species, Diacyclops belgicus (Kiefer), where $\mathrm{Q}_{10}$ was 0.39 considering the mean values of the oxygen consumptions and 0.99 considering the median values.

According to the previous studies (e.g., Van Dijk et al., 1999; Simčič \& Brancelj, 2004), populations having high $\mathrm{E}_{\mathrm{a}}$ would be more susceptible to temperature change than organisms with low $\mathrm{E}_{\mathrm{a}}$. Therefore, much lower $\mathrm{E}_{\mathrm{a}}$ of oxygen consumption for $N$. zagrebensis indicated lower temperature sensitivity to temperature changes in comparison to related hypogean species $N$. stygius. However, $\mathrm{E}_{\mathrm{a}}$ of ETS activity, and $\mathrm{E}_{\mathrm{a}}$ for respiration rate reportedly differed (del Giorgio, 1992; Simčič \& Brancelj, 1997); ETS activity reflects the purely mechanistic nature of the in vitro enzymatic ETS reaction as opposed to the complex and tightly controlled process of respiration. Contrary to $\mathrm{E}_{\mathrm{a}}$ of oxygen consumption, $\mathrm{E}_{\mathrm{a}}$ of ETS activity was higher for $N$. zagrebensis than $N$. stygius. This indicates that ETS activity of $N$. stygius increased less strongly with rising temperature, meaning that the metabolic potential of $N$. stygius was less responsive to temperature changes than that of $N$. zagrebensis. The reason for relatively stable metabolic potential could be the reduction of the cost for mitochondrial biosynthesis and degradation. Moreover, the cost of maintenance of a higher number of mitochondria, e.g., maintenance of proton gradients, and aerobic enzyme capacities, would contribute to a rise of basal metabolism (Rolfe et al., 1999; Pörtner, 2002). Consequently, this increase would cause a shift in energy budget unfavourable to the accumulation of energy reserves for growth and for reproduction (Lannig et al., 2003). This assumption is in accord with the reports of previous studies on the metabolic responses of hypogean and epigean animals to longterm starvation and the subsequent resumption of feeding where hypogean species have a faster and more efficient assimilation of available nutrients during recovery from starvation (Hervant et al., 1999a, 2001; Hervant \& Renault, 2002). The rapid recovery from nutritional stress of troglobiotic organisms was explained by lower exploitation of metabolic potential for current metabolic activity, i.e., lower R/ETS ratio (Simčič et al., 2005). Thus, the optimal relationship between the existing metabolic potential and its 
Table 4. Temperature coefficient $\left(Q_{10}\right)$ and activation energy $\left(E_{a}\right)$ of oxygen consumption in epigean $(E)$ and hypogean $(H)$ crustaceans from various studies.

\begin{tabular}{|c|c|c|c|c|c|}
\hline Taxon & Type & T range $\left({ }^{\circ} \mathrm{C}\right)$ & $\mathbf{Q}_{10}$ & $\mathbf{E}_{\mathrm{a}}\left(\mathbf{k J} \mathbf{~ m o l}^{-1}\right)$ & Source \\
\hline \multirow{2}{*}{ Niphargus zagrebensis } & $\mathrm{E}$ & $5-10$ & 2.21 & 8.1 & Present study \\
\hline & $\mathrm{E}$ & $10-20$ & 1.19 & & Present study \\
\hline \multirow[t]{2}{*}{ Niphargus stygius } & $\mathrm{H}$ & $5-10$ & 2.50 & 35.8 & Present study \\
\hline & $\mathrm{H}$ & $10-20$ & 1.91 & & Present study \\
\hline \multirow[t]{2}{*}{ Niphargus rhenorhodanensis } & $\mathrm{H}$ & $-2-14$ & 7.13 & - & Issartel et al. (2005) \\
\hline & $\mathrm{H}$ & $21-26$ & 0.68 & - & Issartel et al. (2005) \\
\hline \multirow[t]{2}{*}{ Niphargus virei } & $\mathrm{H}$ & $-2-14$ & 16.13 & - & Issartel et al. (2005) \\
\hline & $\mathrm{H}$ & $21-26$ & 0.36 & - & Issartel et al. (2005) \\
\hline \multirow[t]{2}{*}{ Gammarus fossarum } & $\mathrm{E}$ & $-2-14$ & 5.33 & - & Issartel et al. (2005) \\
\hline & $\mathrm{E}$ & $21-26$ & 0.66 & - & Issartel et al. (2005) \\
\hline \multirow[t]{2}{*}{ Asellus aquaticus carniolicus } & $\mathrm{E}$ & $5-10$ & 3.30 & 59.7 & Present study \\
\hline & $\mathrm{E}$ & $10-20$ & 5.54 & & Present study \\
\hline \multirow[t]{2}{*}{ Asellus. aquaticus cavernicolus } & $\mathrm{H}$ & $5-10$ & 14.08 & 77.9 & Present study \\
\hline & $\mathrm{H}$ & $10-20$ & 1.79 & & Present study \\
\hline Proasellus valdensis (PV1) & $\mathrm{H}$ & - & - & 86.4 & Mermillod-Blondin et al. (2013) \\
\hline Proasellus valdensis (PV2) & $\mathrm{H}$ & - & - & 42.4 & Mermillod-Blondin et al. (2013) \\
\hline Proasellus n. sp. 1 & $\mathrm{H}$ & - & - & 53.0 & Mermillod-Blondin et al. (2013) \\
\hline Proasellus n. sp. 2 & $\mathrm{H}$ & - & - & 62.2 & Mermillod-Blondin et al. (2013) \\
\hline
\end{tabular}

exploitation for current energy production, capable of providing the sufficient amount of energy with minimal maintenance costs, is probably realised in subterranean populations at a specific temperature.

$\mathrm{E}_{\mathrm{a}}$-values of oxygen consumption for both subspecies of Asellus were found to be in the range of values reported by Mermillod-Blondin et al. (2013) for three isopod species of genus Proasellus colonizing groundwater habitats characterized by annual temperature amplitude of less than $1^{\circ} \mathrm{C}$ (Table 4). Contrary to the findings for genus Niphargus, $\mathrm{E}_{\mathrm{a}}$-values did not differ significantly between epigean A. a. carniolicus and troglomorphic A. a. cavernicolus. One of the reasons for different respond to temperature between both genera is probably the various amount of food that is available for $N$. stygius and A. a. cavernicolus in comparison to their relative epigean taxa. $N$. stygius is exposed to food depletion in its habitat, while A. a. cavernicolus is not. However, Mermillod-Blondin et al. (2013) demonstrate that populations of three groundwater species could exhibit distinct responses to temperature variation, although they all colonized habitats showing little seasonal temperature fluctuations. Thus, the metabolic responses to temperature change in populations that originate either from thermally stable or variable habitats are heterogeneous, probably due to different combinations of all intrinsic and extrinsic factors that are unique for each population.

In conclusion, the results of this study indicate that metabolic rates in closely related epigean and hypogean species/subspecies are not necessarily dissimilar. Our measurements reveal that either (1) subterranean environment alone does not dictate a decrease of metabolic activity in animals; or (2) both, epigean and subterranean habitats are variable to such an extent that only statistical evaluation of a higher number of populations could tell us what these significant differences are. Moreover, higher sensitivity of oxygen consumption to temperature changes and relatively more stable metabolic potential, as observed in the troglobiotic $N$. stygius, indicates different thermal metabolic characteristics between hypogean and epigean species. On the other hand, the responses of metabolic activities to temperature changes did not differ significantly between both subspecies of genus Asellus. However, the metabolic activity of animals is regulated on several biological levels within their genetic limits that influence how an organism will respond to a particular environmental condition. It is likely that some species/populations are adapted in different ways, which might compensate for the adaptation in metabolic intensity. Further studies of physiological and biochemical traits of closely related animals from various surface and subterranean habitats are needed to provide a more comprehensive picture of the metabolic adaptive mechanisms to the underground environmental conditions.

\section{ACKNOWLEDGEMENTS}

Thanks Jennifer Ellis for Engish revision of the manuscript. We are grateful to three anonymous referees for helpful comments on an earlier version of this manuscript. This study was financially supported by the Slovenian Research Agency (Research Program P1-0255).

\section{REFERENCES}

Angilletta Jr. M.J., 2009 - Thermal adaptation: A theoretical and empirical synthesis. Oxford Universiy Press, New York, 289 p.

https://doi.org/10.1093/acprof:oso/

9780198570875.001.1

Bamstedt U., 1980 - ETS activity as an estimator of respiratory rate of zooplankton populations. The 
significance of variations in environmental factors. Journal of Experimental Marine Biology and Ecology, 42: $267-283$.

https://doi.org/10.1016/0022-0981(80)90181-1

Barton B.A. \& Schreck C.B., 1987 - Metabolic cost of acute physical stress in juvenile steelhead. Transactions of the American Fisheries Society, 116 (2): 257-263. https://doi.org/10.1577/1548-8659(1987)116\%3C257: MCOAPS\%3E2.0.CO;2

Biršejn J.A., 1951 - Presnovodnye osliki (Asellota). In: Pavlovskij E.N. \& Štakel'berg A.A. (Eds.), Fauna SSSR. Rakoobraznye. IAN SSSR, Moskva-Leningrad, p. 44-48.

Cammen L.M., Corwin S. \& Christensen J.P., 1990 Electron transport system (ETS) activity as a measure of benthic macrofaunal metabolism. Marine Ecology Progress Series, 65: 171-182.

https://doi.org/10.3354/meps065171

Culver D.C. \& Poulson T.L., 1971 - Oxygen consumption and activity in closely related amphipod populations from cave and surface habitats. The American Midland Naturalist, 85: 74-84. https://doi.org/10.2307/2423913 del Giorgio P.A., 1992 - The relationship between ETS (electron transport system) activity and oxygen consumption in lake plankton: a cross-system calibration. Journal of Plankton Research, 14: 1723-1741.

https://doi.org/10.1093/plankt/14.12.1723

Delić T, Trontelj P., Rendoš M. \& Fišer C., 2017 The importance of naming cryptic species and the conservation of endemic subterranean amphipods. Scientific Reports, 7: 3391. https://doi.org/10.1038/s41598-017-02938-z

Di Lorenzo T. \& Galassi D.M.P., 2017 - Effect of temperature rising on the stygobitic crustacean species Diacyclops belgicus: Does global warming affect groundwater populations? Water, 9: 951. https://doi.org/10.3390/w9120951

Fanslow D.L., Nalepa T.F. \& Johengen T.H., 2001 Seasonal changes in the respiratory electron transport system (ETS) and respiration rate of the zebra mussel, Dreissena polymorpha in Saginaw Bay, Lake Huron. Hydrobiologia, 448: 61-70. https://doi.org/10.1023/A:1017582119098

Fišer C., 2012 - Niphargus: A Model System for Evolution and Ecology. In: White W.B. \& Culver D.C. (Eds.), Encyclopedia of caves (2 ${ }^{\text {nd }} E d$.). Academic Press, Oxford, p. 556-559.

https://doi.org/10.1016/B978-0-12-383832-2.00082-7

Foulquier A., Malard F., Lefébure T., Douady C.J. \& Gibert J., 2008 - The imprint of Quaternary glaciers on the present-day distribution of the obligate groundwater amphipod Niphargus virei (Niphargidae). Journal of Biogeography, 35: 552-564.

https://doi.org/10.1111/j.1365-2699.2007.01795.x

Gaberščik A., 2002 - Jezero, ki izginja. Monografija o Cerkniškem jezeru. Društvo ekologov Slovenije, Littera picta d.o.o., Ljubljana, 333 p.

Tóth L.G., 1999. Aktivität des Elektronentransportsystems. In: von Tümpling W. \& Friedrich G. (Eds.), Biologische Gewässeruntersuchung. Methoden der Biologischen Wasseruntersuchung 2. Gustav Fischer Verlag, Jena, p. 465-473.

Hervant F. \& Renault D., 2002 - Long-term fasting and realimentation in hypogean and epigean isopods: a proposed adaptive strategy for groundwater organisms. The Journal of Experimental Biology, 205: 2079-2087.

Hervant F., Mathieu J., Barré H., Simon K. \& Pinon C., 1997 - Comparative study on the behavioural, ventilatory, and respiratory responses of hypogean and epigean crustaceans to long-term starvation and subsequent feeding. Comparative Biochemistry and Physiology, 118A: 1277-1283.

https://doi.org/10.1016/S0300-9629(97)00047-9

Hervant F., Mathieu J, \& Messana G., 1998 - Oxygen consumption and ventilation in declining oxygen tension and posthypoxic recovery in epigean and hypogean crustaceans. Journal of Crustacean Biology, 18 (4): 717-727.

https://doi.org/10.1163/193724098X00593

Hervant F., Mathieu J. \& Barre' H., 1999a-Comparative study on the metabolic responses of subterranean and surface-dwelling amphipods to long-term starvation and subsequent refeeding. The Journal of Experimental Biology, 202: 3587-3595.

Hervant F., Mathieu J. \& Culver D.C., 1999b-Comparative responses to severe hypoxia and subsequent recovery in closed related amphipod populations (Gammarus minus) from cave and surface habitats. Hydrobiologia, 392: 197-204.

https://doi.org/10.1023/A:1003511416509

Hervant F., Mathieu J. \& Durand J., 2001 - Behavioural, physiological and metabolical responses to long-term starvation and refeeding in a blind cave-dwelling (Proteus anguinus) and a surface-dwelling (Euproctus asper) salamander. The Journal of Experimental Biology, 204: 269-281.

Hochachka P.W. \& Somero G.N., 2002 - Biochemical Adaptation: Mechanism and Process in Physiological Evolution. Oxford University Press, Oxford, 480 p.

Hüppop K., 2012 - Adaptation to low food. In: White W.B. \& Culver D.C. (Eds), Encyclopedia of caves (2 $2^{\text {nd }} E d$.). Academic Press, Oxford, p. 1-9. https://doi.org/10.1016/B978-0-12-383832-2.00001-3 ISO-standard 6341: 1996 (E). Determination of the inhibition of the mobility of Daphnia magna Straus (Cladocera, Crustacea)-Acute toxicity test (3 ${ }^{\text {rd }}$ Ed.). International Organization for Standardization, Geneve.

Issartel J., Hervant F., Voituron Y., Renault D. \& Vernon P., 2005 - Behavioural, ventilatory and respiratory responses of epigean and hypogean crustaceans to different temperatures. Comparative Biochemistry and Physiology Part A: Molecular \& Integrative Physiology, 141 (1): 1-7.

https://doi.org/10.1016/j.cbpb.2005.02.013

Issartel J., Voituron Y. \& Hervant F., 2007 - Impact of temperature on the survival, the activity and the metabolism of the cave-dwelling Niphargus virei, the ubiquitous stygobiotic N. rhenorhodanensis and the surface-dwelling Gammarus fossarum (Crustacea, Amphipoda). Subterranean Biology, 5: 9-14.

Kenner R.A. \& Ahmed S.I., 1975 - Measurements of electron transport activities in marine phytoplankton. Marine Biology, 33: 119-127. https://doi.org/10.1007/BF00390716

Lampert W., 1984 - The measurement of respiration. In: Downing J.A. \& Rigler F.H. (Eds.), A manual on methods for the assessment of secondary productivity in fresh water. IPB Handbook 17. Blackwell Scientific Publications, Oxford, p. 413-468.

Lannig G., Eckerle L.G., Serendero I., Sartoris F.-J., Fischer T., Knust R., Johansen T. \& Pörtner H.-O., 2003 - Temperature adaptation in eurythermal cod (Gadus morhua): a comparison of mitochondrial enzyme capacities in boreal and Arctic populations. Marine Biology, 142: 589-599. https://doi.org/10.1007/s00227-002-0967-6

Lukančič S., Žibrat U., Mezek T., Jerebic A., Simčič T. \& Brancelj A., 2010 - A new method for early assessment of effects of exposing two non-target crustacean 
species, Asellus aquaticus and Gammarus fossarum, to pesticides, a laboratory study. Toxicology and Industrial Health, 26: 217-228. https://doi.org/10.1177/0748233710362379

Mermillod-Blondin F., Lefour C., Lalouette L., Renault D., Malard F., Simon L. \& Douady C.J., 2013 - Thermal tolerance breadths among groundwater crustaceans living in a thermally constant environment. Journal of Experimental Biology, 216: 1683-1694. https://doi.org/10.1242/jeb.081232

Mezek T., Simčič T., Arts M.T. \& Brancelj A., 2010 - Effect of fasting on hypogean (Niphargus stygius) and epigean (Gammarus fossarum) amphipods: a laboratory study. Aquatic Ecology, 44: 397-408.

https://doi.org/10.1007/s10452-009-9299-7

Muskó I.B., G.-Tóth L. \& Szábo E.,1995 - Respiration and respiratory electron transport system (ETS) activity of two amphipods: Corophium curvispinum G.O. Sars and Gammarus fossarum Koch. Polish Archives of Hydrobiology, 42: 547-558.

Packard T.T., 1971 - The measurement of respiratory electron transport activity in marine phytoplankton. Journal of Marine Research, 29: 235-244.

Packard T.T., Devol A.H. \& King F.D., 1975 - The effect of temperature on the respiratory electron transport system in marine plankton. Deep-Sea Research, 22: 237-249. https://doi.org/10.1016/0011-7471(75)90029-7

Pörtner H.O., 2002 - Physiological basis of temperaturedependent biogeography: trade-offs in muscle design and performance in polar ectotherms - Review. Journal of Experimental Biology, 205: 2217-2230.

Prevorčnik S., Verovnik R. \& Sket B., 2002 - Diversity of Asellus aquaticus (Crustacea: Isopoda) subpopulations in the Postojna-Planina Cave System testifies for recurrent immigration of the species underground. XVI International Symposium of Biospeleology, Abstracts, p. 88.

Prevorčnik S., Blejec A. \& Sket B., 2004 - Racial differentiation in Asellus aquaticus (L.) (Crustacea: Isopoda: Asellidae). Archiv für Hydrobiologie, 160 (2): 193-214.

https://doi.org/10.1127/0003-9136/2004/0160-0193

Prosser C.L., 1991 - Temperature. In: Prosser C.L. (Ed.), Environmental and metabolic animal physiology. WileyLiss, New York, p. 109-166.

Racovitza E.G., 1925 - Notes sur les Isopodes. 13. Morphologie et phylogénie des Antennes II. Archives de Zoologie Experimentale et Generale, 63: 533-622.

Randall D., Burgger W. \& French K., 1997 - Eckert Animal Physiology: Mechanisms and Adaptations $14^{\text {th }}$ Ed). W.H. Freeman and Company, New York, 723 p.

Rolfe D.F.S., Newman J.M.B., Buckingham J.A., Clark M.G. \& Brand M.D., 1999 - Contribution of mitochondrial proton leak to respiration rate in working skeletal muscle and liver and to SMR. American Journal of Physiology, 276: C692-C699.

https://doi.org/10.1152/ajpcell.1999.276.3.C692

Salin K., Voituron Y., Mourin J. \& Hervant F., 2010 - Cave colonization without fasting capacities: An example with the fish Astyanax fasciatus mexicanus. Comparative Biochemistry and Physiology Part A: Molecular \& Integrative Physiology, 156: 451-457. https://doi.org/10.1016/j.cbpa.2010.03.030

Simčič T., 2005 - Respiratory electron transport system (ETS) activity and respiration rate in cold-stenothermal and eurythermal chironomid larvae from high-mountain lakes. Archiv fuer Hydrobiologie, 162: 399-415 https://doi.org/10.1127/0003-9136/2005/0162-0399
Simčič T. \& Brancelj A., 1997 - Electron transport system (ETS) activity and respiration rate in five Daphnia species at different temperatures. Hydrobiologia, 360: 117-125.

https://doi.org/10.1007/978-94-011-4964-8 13

Simčič T. \& Brancelj A., 2000 - Energy exploitation in Chirocephalus croaticus (Steuer, 1899) (Crustacea: Anostraca): survival strategy in an intermittent lake. Hydrobiologia, 437: 157-163. https://doi.org/10.1023/A:1026507024238

Simčič T. \& Brancelj A., 2001 - Seasonal dynamics of metabolic activity of the Daphnia community in Lake Bled (Slovenia). Hydrobiologia, 442: 319-328.

https://doi.org/10.1023/A:1017542401205

Simčič T. \& Brancelj A., 2003 - Estimation of the proportion of metabolically active mass in the amphipod Gammarus fossarum. Freshwater Biology, 48: 1093-1099. https://doi.org/10.1046/j.1365-2427.2003.01075.x

Simčič T. \& Brancelj A., 2004 - Respiratory electron transport system (ETS) activity as an estimator of the thermal tolerance of two Daphnia hybrids. Journal of Plankton Research, 26: 525-534.

https://doi.org/10.1093/plankt/fbh056

Simčič T. \& Brancelj A., 2007 - The effect of light on oxygen consumption in two amphipod crustaceans: the hypogean Niphargus stygius and the epigean Gammarus fossarum. Marine and Freshwater Behaviour and Physiology, 40: 141-150.

https://doi.org/10.1080/10236240701452465

Simčič T., Lukančič S. \& Brancelj A., 2005 - Comparative study of electron transport system activity and oxygen consumption of amphipods from caves and surface habitats. Freshwater Biology, 50: 494-501. https://doi.org/10.1111/j.1365-2427.2005.01339.x

Simčič T., Pajk F., Vrezec A. \& Brancelj A., 2012. - Size scaling of whole-body metabolic activity in the noble crayfish (Astacus astacus) estimated from measurements on a single leg. Freshwater Biology, 57: 39-48. https://doi.org/10.1111/j.1365-2427.2011.02692.x

Simčič T., Pajk F., Jaklič M., Brancelj A. \& Vrezec A., 2014 - The thermal tolerance of crayfish could be estimated from respiratory electron transport system activity. Journal of Thermal Biology, 41: 21-30.

https://doi.org/10.1016/j.jtherbio.2013.06.003

Simčič T., Jesenšek D. \& Brancelj A., 2017 - Metabolic characteristics of early life history stages of native marble trout (Salmo marmoratus) and introduced brown trout (Salmo trutta) and their hybrids in the Soča River. Ecology of Freshwater Fish, 26: 141-149.

https://doi.org/10.1111/eff.12264

Sket B., 1958 - Prispevek $k$ poznavanju naših amfipodov I., II. (Beitrag zur Kenntnis unserer Amphipoden I., II.). Biološki vestnik, 6: 66-75.

Sket B., 1965 - Taksonomska problematika vrste Asellus aquaticus (L.) Rac. (Crust., Isopoda), s posebnim ozirom na populacije $v$ Sloveniji (Taxonomische Problematik der Art Asellus aquaticus (L.) Rac. mit besonderer Rucksicht auf die Populationen Sloweniens). Razprave SAZU, cl. IV., 8: 177-221.

Sket B.,1981 - Razširjenost, ekološkiznačaj in filogenetski pomen panonske slepe postranice Niphargus valachicus (Amphipoda, Gammaridae) (Distribution, ecological character, and phylogenetic importance of Niphargus valachicus). Biološki vestnik, 29 (1): 87-103.

Sket B., 1994 - Distribution of Asellus aquaticus (Crustacea: Isopoda: Asellidae) and its hypogean populations at different geographic scales, with a note on Proasellus istrianus. Hydrobiologia, 287: 39-47.

https://doi.org/10.1007/BF00006895 
Sket B., 1996 - The ecology of the anchihaline caves. Trends in Ecology and Evolution, 11 (5): 221-225. https://doi.org/10.1016/0169-5347(96)20031-X

Sket B., 2008-Can we agree on an ecological classification of subterranean animals. Journal of Natural History, 42: 1549-1563. https://doi.org/10.1080/00222930801995762

Statistični urad RS (accessed feb 2018) Povprečne letne in mesečne temperature zraka $\left({ }^{\circ} \mathrm{C}\right)$ po meteoroloških postajah, Slovenija, letni podatki do 2014.

van Dijk P.L., Tesch C., Hardewig I.I. \& Portner H.-O., 1999 - Physiological disturbances at critically high temperatures: a comparison between stenothermal antarctic and eurythermal temperate eelpouts (Zoarcidae). Journal of Experimental Biology, 24: 3611-3621.

Verovnik R., Sket B. \& Trontelj P., 2004 - Phylogeography of subterranean and surface populations of water lice Asellus aquaticus (Crustacea: Isopoda). Molecular Ecology, 13: $1519-1532$.

https://doi.org/10.1111/j.1365-294X.2004.02171.x
Verovnik R., Sket B. \& Trontelj P., 2005 - The colonization of Europe by the freshwater crustacean Asellus aquaticus (Crustacea: Isopoda) proceeded from ancient refugia and was directed by habitat connectivity. Molecular Ecology, 14: 4355-4369.

https://doi.org/10.1111/j.1365-294X.2005.02745.x

Verovnik R. Prevorčnik S. \& Jugovic J., 2009 Description of a neotype for Asellus aquaticus Linné, 1758 (Crustacea: Isopoda: Asellidae), with description of a new subterranean Asellus species from Europe. Zoologischer Anzeiger, 248: 101-118.

https://doi.org/10.1016/j.jcz.2009.03.001

Žagar A., Simčič T., Carretero M.A. \& Vrezec A., 2015 The role of metabolism in understanding the altitudinal segregation pattern of two potentially interacting lizards. Comparative Biochemistry and Physiology Part A: Molecular \& Integrative Physiology, 179: 1-6. https://doi.org/10.1016/j.cbpa.2014.08.018 